\title{
Effects of estuarine environmental conditions on population dynamics of young-of-the-year gulf menhaden
}

\author{
Linda A. Deegan* \\ Department of Marine Science, Louisiana State University, Baton Rouge, Louisiana 70803, USA
}

\begin{abstract}
Environmental factors, primarily river discharge and winter temperatures, are strongly correlated with growth and survival of young-of-the-year gulf menhaden Brevoortia patronus in Fourleague Bay, Louisiana, USA. Gulf menhaden were found in highest abundance from February to November. They first use marsh creeks and then in early summer they migrate out into deeper open bay areas where they remain until late summer or fall. This migration pattern coincides with the productivity peaks in marsh and open bay areas. Instantaneous growth coefficients were slightly different between years $(1982=0.005,1983=0.004)$. Mortality rates were different between year-classes $(1982$ year-class $=0.007 ; 1983$ year-class $=0.018)$, but not between habitats within a year-class. In periods of high river discharge and cooler spring temperatures, fish apparently grew more slowly and mortality rates were higher. This is consistent with other studies that correlated catch of adult gulf menhaden with environmental factors during their juvenile estuarine stay.
\end{abstract}

\section{INTRODUCTION}

Gulf menhaden Brevoortia patronus is a pelagic, schooling, clupeid which supports one of the largest commercial fisheries by weight in North America (Smith et al. 1987). Young-of-the-year gulf menhaden are ubiquitous members of northern Gulf of Mexico estuarine nekton communities, and occupy fresh to brackish waters almost year-round using both marsh and open bay habitats (Fig. 1) (Hinchee 1977, Simoneaux 1979, Lassuy 1983, Deegan \& Thompson 1985). Because of the growing interest in a flexible fishing season commensurate with the abundance of the adult fish, and the indications that factors during their estuarine stay strongly influence year-class strength in the fishery (Stone 1976, Guillory \& Bejarano 1980, Guillory et al. 1983), a clear understanding of the relationship between menhaden and estuaries is needed. Although the species has been frequently studied (Reintjes \& Pacheco 1966, Christmas et al. 1982, Lassuy 1983), several aspects of its life history in estuaries are not well known. There is little information on the period of residence in different estuarine

\footnotetext{
- Present address: The Ecosystems Center, Marine Biological Laboratory, Woods Hole, Massachusetts 02543, USA
}

habitats and, furthermore, nothing is known about natural mortality and growth rates, or environmental factors which affect these rates during their estuarine residence. Low winter temperatures, high salinities and low turbidity during their stay in estuaries are correlated with poor year-classes (Christmas et al. 1982, Guillory et al. 1983). These environmental factors are believed to influence growth and mortality rates of young-of-the-year by affecting food supply, and exceeding tolerance limits.

In this study I document the timing of migration, the duration of residence in marsh and open bay habitats, and estimates of growth and natural mortality rates of young-of-the-year gulf menhaden, and discuss the influence of environmental conditions and productivity cycles on population dynamics.

\section{MATERIALS AND METHODS}

Site description. Fourleague Bay, Louisiana, USA, is a small, shallow (depth about $1 \mathrm{~m}$ ) estuary with ca 10000 ha open bay and 50000 ha of intermediate to brackish marsh (Fig. 2). Open bay stations were at the northern end, the middle, and southern end. The northern end open bay station was ca $1.5 \mathrm{~m}$ deep and had a 


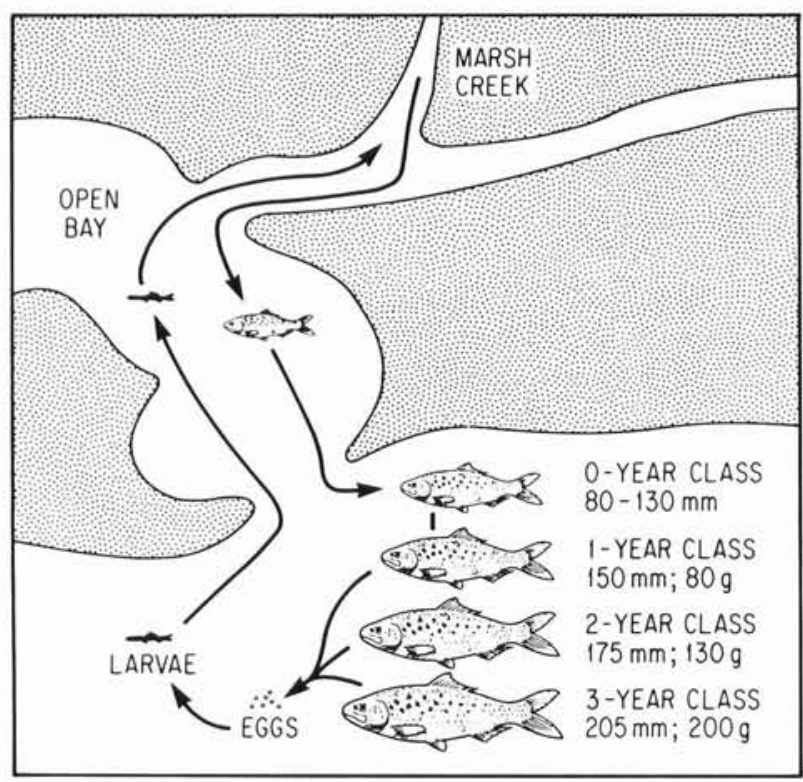

Fig. 1. Brevoortia patronus. Life history of gulf menhaden in Louisiana

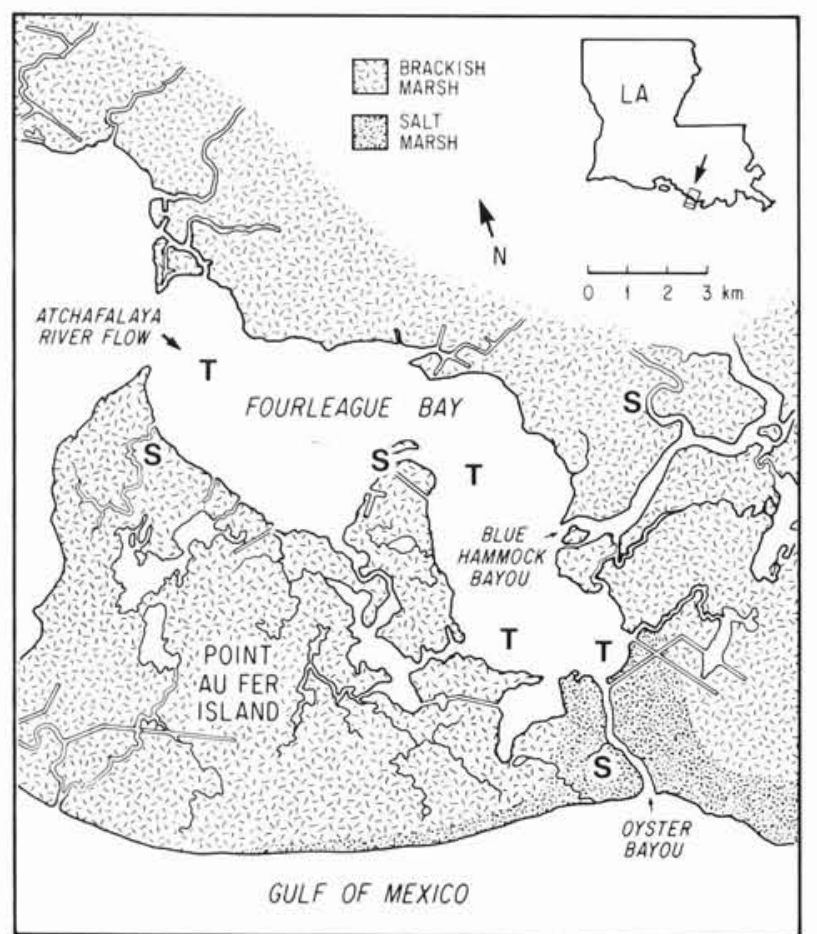

Fig. 2. Fourleague Bay, Louisiana. Trawl samples are indicated by a $\mathrm{T}$; seine samples by an $\mathrm{S}$. The northern end of the bay opens into Atchafalaya Bay, and receives about $20 \%$ of the flow of the Atchafalaya River

bottom substrate of fine mud and Rangia shells. The middle bay station was about $1 \mathrm{~m}$ deep and had bottom substrate of fine soft mud. The stations at the southern end were slightly less than $1 \mathrm{~m}$ deep and had bottom substrates of fine soft mud. The marsh was vegetated with Juncus sp., Spartina patens, Spartina alterniflora,
Distichilis spicata, Scirpus sp. and Sagittaria sp. Marsh stations were in small tidal creeks between 1 and $2 \mathrm{~m}$ deep and 5 to $7 \mathrm{~m}$ wide, with silty muddy bottoms. The northern end of the bay opens into Atchafalaya Bay, a freshwater bay which is the mouth of the Atchafalaya River. Approximately $20 \%$ of the flow of the Atchafalaya River enters Fourleague Bay via the northern opening and maintains a salinity gradient from fresh to brackish (Madden et al. 1988).

Field sampling. Gulf menhaden were sampled monthly from July 1981 to December 1983 (except January 1983) from open bay habitats using replicate $10 \mathrm{~min}$ otter trawl tows $(4.9 \mathrm{~m}, 19.1 \mathrm{~mm}$ mesh wings, and $4.8 \mathrm{~mm}$ mesh cod end) that covered ca 0.35 ha per tow. Gulf menhaden were sampled monthly at marsh creek habitats from February 1982 to March 1983, except January 1983, using a $15 \times 2 \mathrm{~m}, 4.8 \mathrm{~mm}$ mesh, bag seine and covered ca 0.15 ha per haul.

Water temperature, salinity (Yellow Springs Instrument Co., Salinity, Conductivity and Temperature meter, model 33) and Secchi disk depth were measured at each station during monthly collections. Fish were frozen, or preserved in either $95 \%$ isopropyl alcohol or $10 \%$ formaldehyde. Fish preserved in formaldehyde were later transferred to $40 \%$ isopropyl alcohol.

Laboratory analysis. Total number of gulf menhaden per sample was counted and wet weight (to the nearest $0.01 \mathrm{~g}$ ) and standard length (to nearest $\mathrm{mm}$ ) for each individual measured. If the total number of menhaden in a sample exceeded 200, a subsample was measured for length.

Calculation of growth rate. Separate estimates of growth rate were calculated for each year-class using length-frequency data combined for marsh creeks and open bay stations. The instantaneous growth coefficient (G) was estimated by calculating the average time individuals in a year-class attained a certain length (DeAngelis et al. 1980). Growth is exponential during this time and can be described by the equation

$$
\mathrm{L}=\mathrm{L}_{\mathrm{o}} \mathrm{e}^{\mathrm{Gt}}
$$

where $\mathrm{L}=$ length $(\mathrm{mm}) ; \mathrm{G}=$ instantaneous relative growth coefficient $\left(\mathrm{d}^{-1}\right) ; \mathrm{L}_{\mathrm{o}}=$ initial size (in $\mathrm{mm}$ ) of the fish at the entrance to the estuary; $t=$ time it took the average individual in that length-class to achieve the indicated size. A regression of $\ln (\mathrm{L})$ against $\ln (\mathrm{t})$ is linear with slope of $G$ and an intercept of $\ln \left(\mathrm{L}_{\mathrm{o}}\right)$. A value for $\mathrm{G}$ obtained in this fashion represents the average growth rate of the population during the time period (Ricker 1979).

Calculation of natural mortality. Length-frequency data were combined with abundance estimates to derive estimates of natural mortality rate for marsh and open bay habitats. Instantaneous mortality (Z) was estimated using a partial differential equation model 
describing the interaction of growth and mortality based on the dynamics of length distribution and abundance over time (DeAngelis et al. 1980). This technique assumes: (1) that fish can only enter the population at the smallest size considered, (2) that fish only leave the population through death, (3) that growth is exponential over the time period and size range of fish considered, and (4) that mortality can be described by the generally recognized model

$$
\mathrm{N}_{\mathrm{t}}=\mathrm{N}_{\mathrm{o}} \mathrm{e}^{-\mathrm{Zt}}
$$

where $\mathrm{N}_{\mathrm{t}}=$ number at time $\mathrm{t}_{;} \mathrm{N}_{\mathrm{o}}=$ initial abundance; $\mathrm{Z}=$ mortality coefficient which is constant over the size range of fish and time period considered. The time $t_{0}$ is the first time at which the smallest size individual considered is captured. DeAngelis et al. (1980) have shown that the number of fish at length $\mathrm{L}$ at time $t$ is proportional to length by the following

$$
\mathrm{N}(\mathrm{L}, \mathrm{t})=\mathrm{aL}^{-(\mathrm{Z}+\mathrm{G}) / \mathrm{G}}=a \mathrm{~L}^{\mathrm{m}}
$$

where $(Z+G) / G=-m$ or $Z=G(m+1)$. Thus, $Z$ can be estimated from knowledge of $\mathrm{G}$ and $\mathrm{m}$. Regression of $\ln$ (total number at length) against $\ln$ (length) is linear with a slope of $\mathrm{m}$, and an intercept of a.

Although DeAngelis et al. (1980) did not give a method of calculating the confidence limits of $Z$, these can be estimated from knowledge of the variance of $G$ and $\mathrm{m}$ (Deegan 1985). Because $\mathrm{Z}$ is the product of 2 randomly distributed, independent variables, $\mathrm{G}$ and $\mathrm{m}$, the variance of $Z$ can be estimated from the variances for $\mathrm{G}$ and $\mathrm{m}$ from the following

$$
\operatorname{Var}(\mathrm{Z})=(\mathrm{G})^{2} \cdot \operatorname{var}(\mathrm{m})+(\mathrm{m})^{2} \cdot \operatorname{var}(\mathrm{G})
$$

Assuming $\mathrm{Z}$ has a normal distribution, the $95 \%$ confidence limits on $\mathrm{Z}$ are approximately $2 \times$ Standard Error.

This method of estimating mortality has several advantages over other techniques (Ricker 1975, Tyler \& Gallucci 1980, White et al. 1982). First, it can be used for populations in which recruitment occurs during the sampling period (DeAngelis et al. 1980). This is important because recruitment into the estuary occurs over ca 3 to $4 \mathrm{mo}$. Secondly, this method can incorporate size-dependent phenomena. For example, DeAngelis et al. (1980) noted a change in catch efficiency at $10 \mathrm{~mm}$ length in their study of young crappie Pomoxis nigromaculatus. This resulted in a slightly different slope for the relationship of total number against length before $10 \mathrm{~mm}$ compared to after $10 \mathrm{~mm}$. Developing 2 lines, one on fish less than $10 \mathrm{~mm}$ and one on fish greater than $10 \mathrm{~mm}$, eliminates the bias in the estimate due to changes in catch efficiency, and can be effectively used to develop estimates for populations with size-related phenomena.
Marsh and open bay habitats were analyzed separately for several reasons. First, because of differing catch efficiencies, abundances derived from seines are not directly comparable with those obtained from trawls. Because the relative abundance estimates are not directly equivalent, they cannot be used satisfactorily in the same model. Secondly, gulf menhaden migrate between the 2 habitats in a size-related manner. This is a problem because one assumption of the model used to estimate mortality is that fish leave the population only through death. If fish also emigrate, then the model actually estimates the rate of decrease of the population caused by a combination of death and emigration. The mortality rate can be approximated, however, if the emigration rate is very small over the size range considered. I have taken advantage of the size-related migration from marsh to open bay to minimize the effect of migration on the estimate. Within each habitat, emigration can be assumed to be fairly small if the analysis is done over the size range of fish that predominate in that habitat. Therefore, the size ranges used in the mortality estimate were restricted to 20 to $50 \mathrm{~mm}$ in the marsh creek, and 50 to $90 \mathrm{~mm}$ in the open bay area.

Data analysis. This study encompassed the youngof-the-year of 3 year-classes of gulf menhaden. The 1981 year-class was in the estuary when sampling began in July 1981; the 1982 year-class first entered in November 1981, and their primary year of estuarine residence was 1982. The 1983 year-class first entered the estuary in November 1982, and their primary year of estuarine residence was 1983. Abundances were converted to density (fish ha ${ }^{-1}$ ) based on area covered by the seine or trawl. Average abundances (number per hectare) were calculated using the $\ln (n+1)$ transformation because fish abundance data generally conform to the negative binomial distribution (Clark 1974).

Analysis of variance (ANOVA) was used to test for differences in water temperature, salinity, and Secchi disk depth between habitats and years (Snedecor \& Cochran 1967). Differences between open bay and marsh habitat were tested using an ANOVA model that included 2 main effects (habitat and month) and a 2 factor interaction (month $\times$ habitat). To test for differences between years for open bay stations, the ANOVA model included 2 main effects (month and year) and a 2 factor interaction (month $\times$ year). $F$ values are given as the value for the comparison, the error degrees of freedom (df), and the significance level. Test degrees of freedom is 1 , unless otherwise stated. Least-squares regression was used to develop linear equations for growth and abundance data. Analysis of covariance was in general used to test for differences in slope or level of regression lines (Warren 1974, Draper \& Smith 1981). To test for differences in 
growth rates between year-classes, separate regression equations for each year-class were compared to an overall regression based on the year-classes combined. If the lines were found to have the same slope, they were further tested for a difference in level (or intercept). To test for differences in $\mathrm{m}$ between habitats, the same procedure was followed for the relationship of total number against length, calculating separate lines for each habitat and year-class. Student's t was used to test for differences in mortality estimates between habitats within year-classes and between year-classes (Snedecor \& Cochran 1967). Estimates were considered to be different at the $5 \%$ level if the t-value was greater than 2.0. Correlation between variables was measured using the Pearson product-moment statistic (Draper \& Smith 1981).

\section{RESULTS}

\section{Physical parameters}

The physical parameters of the water in Fourleague Bay are highly influenced by the interaction of Atchafalaya River discharge and weather events. Atchafalaya River discharge peaks in April through June and then declines through the summer and into the fall (Fig. 3). Local rains some years increase discharge slightly in the fall. Over the course of this study, total river discharge was lowest in 1981, slightly higher in
1982, and highest in 1983. River discharge in 1983 was above the $40 \mathrm{yr}$ mean and river level continued higher than normal all year. Salinity is clearly influenced by river flow (Fig. 3). Salinities were generally highest (10 to $15 \%$ ) in the early fall (September-October), and lowest ( 0 to $2.5 \%$ ) in the late winter-spring (February-May). The high value for salinity in May 1989 is probably the result of south winds associated with a frontal event pushing Gulf water into the bay (Madden et al. 1988). Salinity did not differ between open bay and marsh creek habitats $(\mathrm{F}=0.36$, df $=185$, $p=0.550$ ). The mean salinity among years was not different $(F=0.04, \mathrm{df}=2,153, \mathrm{p}=0.961)$, however 1983 had a prolonged low salinity period in the spring compared to 1982 ( $\mathrm{f}=3.49$, df $=153$, $\mathrm{p}<0.001$ ). Secchi disk depth was high (30 to $50 \mathrm{~cm}$ ) in the early fall, and low $(0$ to $5 \mathrm{~cm}$ ) in the winter and spring (Fig. 3). The low Secchi value in May 1982 demonstrates the increase in turbidity due to strong southerly winds still stirring up bottom sediments. Secchi disk depth differed among months, but there was no difference between marsh and open bay habitats $(\mathrm{F}=0.34$, $\mathrm{df}=105, \mathrm{p}=0.563)$, or among open bay stations among years $(F=6.33$, df $=2,2, p=0.14)$.

Marsh creeks warmed up faster in the spring, were hotter in the summer, and tended to be cooler in the winter than open bay stations $(\mathrm{F}=8.94$, df $=192$, $\mathrm{p}<0.003$; Fig. 3). Water temperatures ranged from $32^{\circ} \mathrm{C}$ in July and August to between 10 and $15^{\circ} \mathrm{C}$ in December and January. There was no difference in

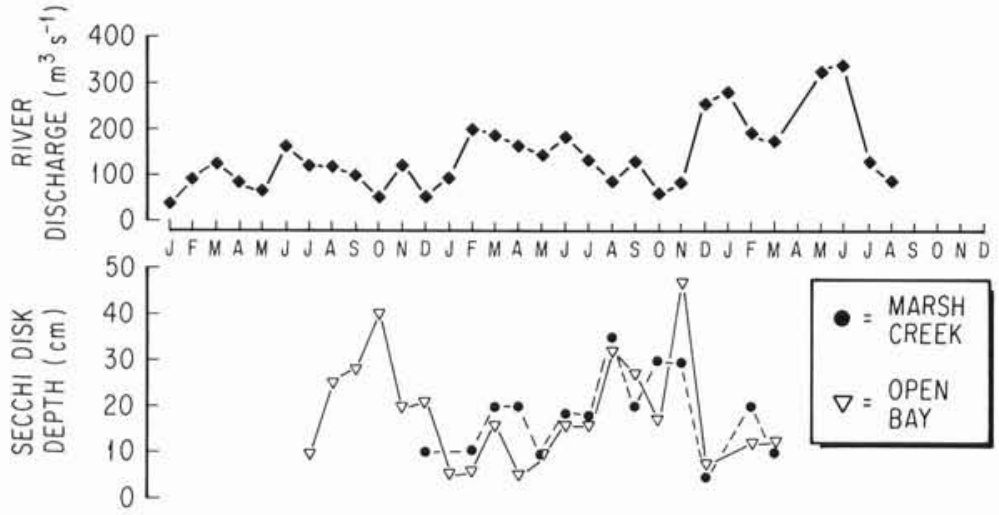

立

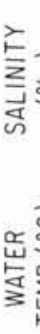

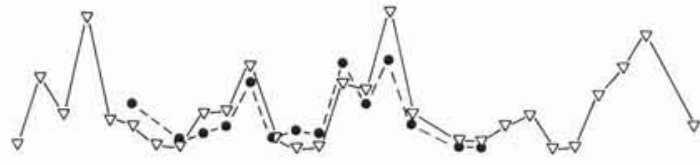

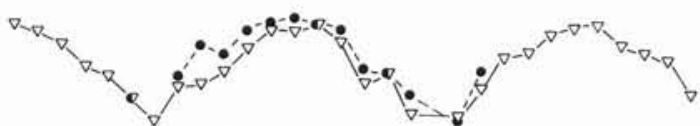

FMAM JJASONDJFMAMJJASONDJFMAMJJASOND

1981
1982
Fig. 3. River discharge, Secchi disk depth, salinity and water temperature in Fourleague Bay, Louisiana, 1981 through 1983 
average water temperature at open bay stations among years. However, February and March 1983 were much colder than the previous years $(\mathrm{F}=3.18$, df $=153$, $\mathrm{p}<0.001$ ). The average temperatures of open bay stations were 17 and $12^{\circ} \mathrm{C}$, in February 1982 and 1983 respectively, and 19 and $17^{\circ} \mathrm{C}$ for March 1982 and 1983 respectively. Water temperatures in marsh stations during these months were higher than open bay stations, and also showed the colder temperatures characteristic of 1983; water temperatures were 20 and $11^{\circ} \mathrm{C}$ for February 1982 and 1983 respectively, and 27 and $22^{\circ} \mathrm{C}$ for March 1982 and 1983 respectively.

\section{Migration pattern}

Juvenile gulf menhaden were found in Fourleague Bay year-round; however, each year-class was greatest in abundance from February to November and sequentially used marsh and open bay habitats (Figs. $4 \& 5$ ).

Changes in abundance and average length illustrate the basic migration pattern (Figs. 4 \& 5). Larvae (19 to $23 \mathrm{~mm}$ ) were found in low numbers in the open bay areas from November until March, and were absent from open bay areas by April. After entering the estuary, larvae moved to marsh creeks where transformation from larvae to juvenile occurred. Fish density was highest in tidal creeks in March or April, at about 15 to 20000 fish ha ${ }^{-1}$ and an average size of 30 to $40 \mathrm{~mm}$. Abundance in the creek declined to around 200 fish $\mathrm{ha}^{-1}$ by June, when at ca 45 to $50 \mathrm{~mm}$, they began to move into open bay areas. The mean length of individuals in the open bay was larger than the mean
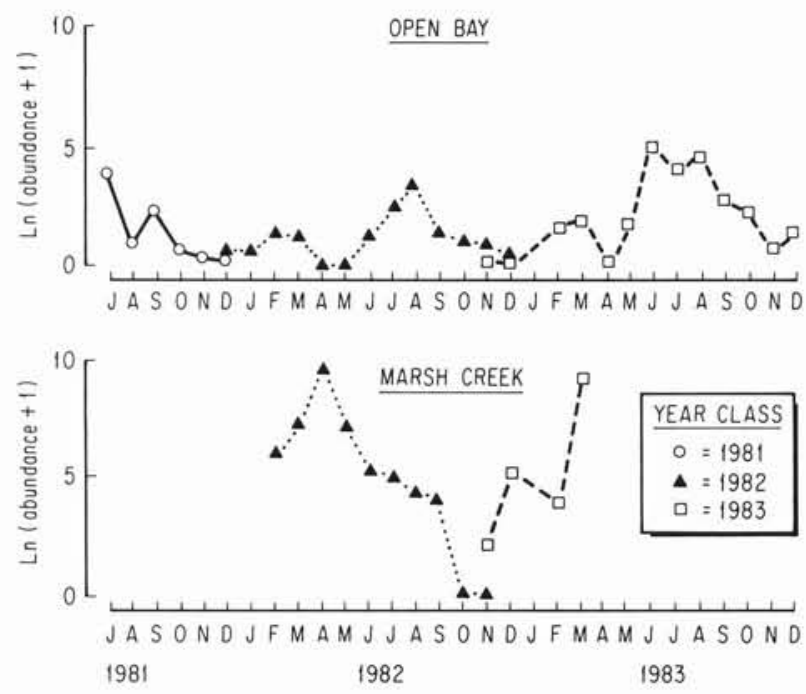

Fig. 4. Brevoortia patronus. Average abundance of menhaden at open bay and marsh stations. (ㅇ) 1981 year-class; (4) 1982 year-class; (ㅁ) 1983 year-class. April, May 1982 and April 1983 in the open Bay area are zero catches length of individuals left in tidal creeks (Fig. 5). After June, menhaden increased in abundance in the open bay and schools were spread over a large area and densities were lower. The average size and range of the individuals in the open bay in June and July increased slightly. Abundance of juveniles in the open bay was highest in the summer (July-August), and declined in the fall to zero, after emigration to offshore areas. Some individuals returned to the estuary in the spring (February to April) as 1-yr-olds.

Although the pattern was similar among years, there were year-to-year differences in the timing of migration. For instance, the 1981 year-class was present in the estuary until February 1982; the 1982 year-class, however, was completely missing from the estuary by November 1982. There were also differences in size at comparable times between years. For example, the average length of fish in the marsh creek habitat in March 1982 was larger than the average size of fish from March 1983 (30 vs 25 mm).

The size frequency distribution of menhaden by habitat indicates that smaller fish $(<50 \mathrm{~mm})$ were found predominantly in the marsh habitat, while larger fish were found predominantly in the open bay habitat (Fig. 6). Small numbers of intermediate size menhaden ( 25 to $40 \mathrm{~mm}$ ) were found in the open bay, but their low numbers indicate this is not their primary area of residence. Larvae (20 to $25 \mathrm{~mm}$ ) were found in the open bay areas in winter/spring as they passed through on their way to marsh habitats. Approximately $96 \%$ of the fish captured in the marsh creek were less than $50 \mathrm{~mm}$; $78 \%$ of the fish captured in the open bay were larger than $50 \mathrm{~mm}$.
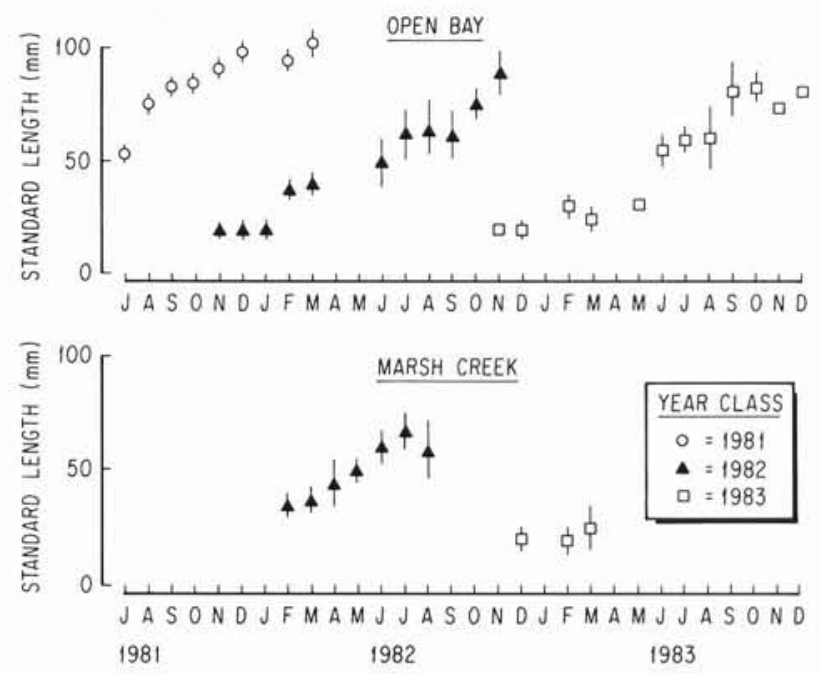

Fig. 5. Brevoortia patronus. Average length of juvenile gulf menhaden at open bay and marsh habitats for 3 year-classes of fish. (ㅇ) 1981 year-class; ( $\mathbf{\Lambda}) 1982$ year-class; (ㅁ) 1983 yearclass. Vertical bar is one standard error; symbols are sometimes larger than the standard error 


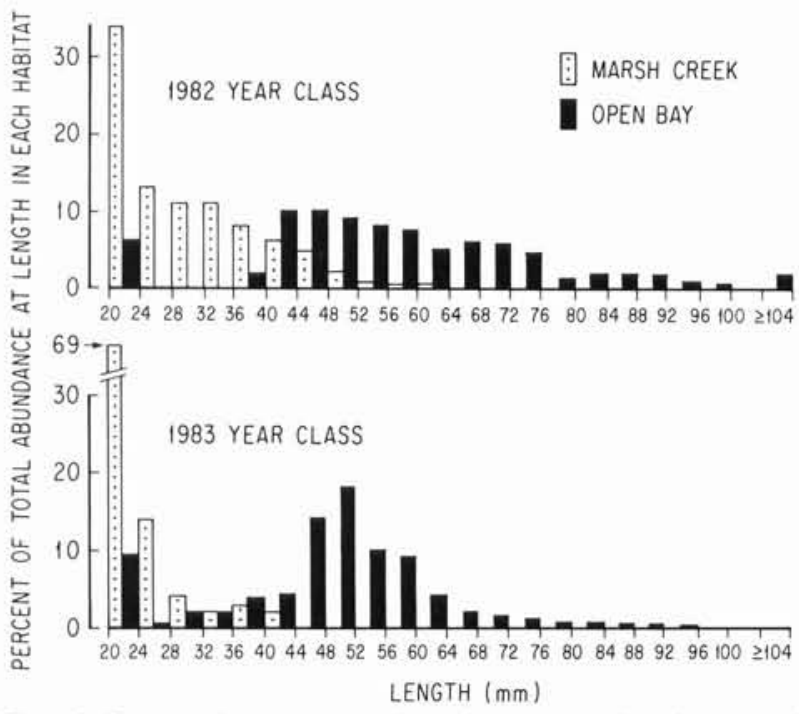

Fig. 6. Brevoortia patronus. Size frequency distribution of young-of-the-year gulf menhaden in marsh and open bay habitats in Fourleague Bay, Louisiana

\section{Growth}

Young-of-the-year gulf menhaden grew rapidly (Fig. 7). Menhaden increased in length ca 5 -fold, from 20 to $100 \mathrm{~mm}$. The 1981 year-class had the single largest fish $(146 \mathrm{~mm})$ and had more fish that were larger than $100 \mathrm{~mm}$ than either the 1982 or the 1983 year-classes. The 1982 year-class also had an end-of-the-year average length that was larger than the 1983 year-class (Fig. 7).

The 1982 year-class had a $G$ value $(G=0.0052)$ higher than the 1983 year-class $(G=0.0045)$, although the values for $\mathrm{G}$ did not test as different at the $5 \%$ significance level (Table 1). Growth curves were constructed for all 3 year-classes, however data on the 1981 year-class does not cover the entire range of individuals found in the estuary and the equation developed may not be an adequate description of the growth of this year-class. The estimate of $29.9 \mathrm{~mm}$ for $\mathrm{L}_{\mathrm{o}}$, well above the 18 to $22 \mathrm{~mm}$ size range for $\mathrm{L}_{\mathrm{o}}$ based on length-frequency analysis, indicated the inappropriateness of the growth equation developed for the 1981 year-class. The estimate values for $\mathrm{L}_{\mathrm{o}}$ for the other year-classes $(1982$ year-class $=20.06 \mathrm{~mm}, 1983$ yearclass $=19.10 \mathrm{~mm}$ ) were within the expected range. Hence, comparisons of growth equations were restricted to the 1982 and 1983 year-classes.

\section{Mortality}

Mortality was estimated for the 1982 and 1983 yearclasses for marsh and open bay habitats. Abundance

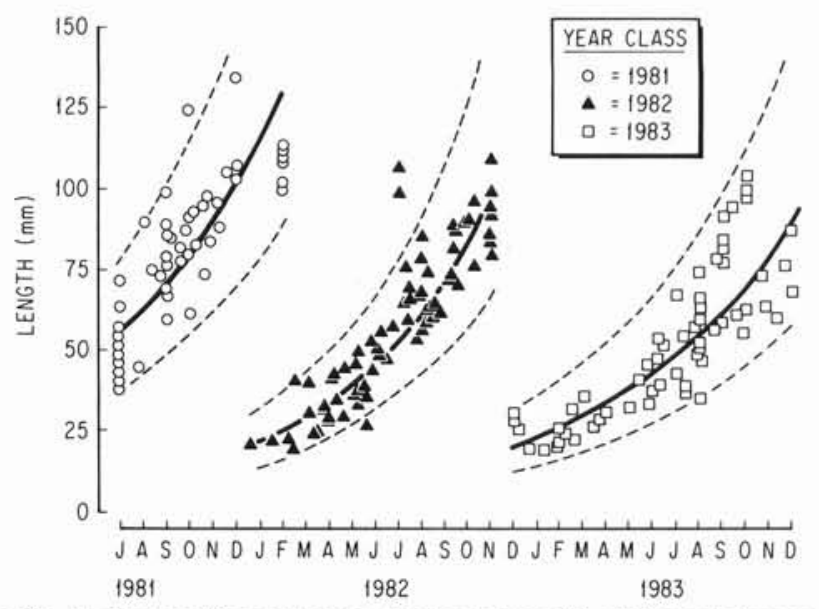

Fig. 7. Brevoortia patronus. Average growth of 3 year-classes of young-of-the-year gulf menhaden in Fourleague Bay, Louisiana. Length of fish is plotted against average date yearclass reached that length (DeAngelis et al. 1980). Lines are the back-transformed best least squares fit and $95 \%$ confidence limits regression equations given in Table 1. () 1981 yearclass; (4) 1982 year-class; (ㅁ) 1983 year-class

Table 1. Brevoortia patronus. Regression coefficients (and standard errors) with corresponding statistical analysis for growth equations of 3-year-classes of young-of-the-year gulf menhaden in Fourleague Bay, Louisiana. Model fitted was $\ln (\mathrm{L})-\ln \left(\mathrm{L}_{\mathrm{o}}\right)+\mathrm{G} \ln (\mathrm{t}) . \mathrm{t}_{\mathrm{o}}:$ November 1

\begin{tabular}{|c|c|c|c|c|c|c|c|}
\hline \multicolumn{8}{|c|}{ Coefficients of the growth equations } \\
\hline Year-class & \multicolumn{2}{|c|}{$\begin{array}{c}\text { Intercept } \\
\ln \left(\mathrm{L}_{\mathrm{o}}\right)\end{array}$} & \multicolumn{2}{|c|}{$\begin{array}{c}\text { Slope } \\
\text { (G) }\end{array}$} & $\mathrm{n}$ & $r^{2}$ & F-value \\
\hline 1981 & \multicolumn{2}{|c|}{$\begin{array}{c}3.390 \\
(0.096)\end{array}$} & \multicolumn{2}{|c|}{$\begin{array}{c}0.0040 \\
(0.0004)\end{array}$} & 42 & 0.72 & 101.9 \\
\hline 1982 & \multicolumn{2}{|c|}{$\begin{array}{l}2.999 \\
(0.081)\end{array}$} & \multicolumn{2}{|c|}{$\begin{array}{c}0.0052 \\
(0.0004)\end{array}$} & 43 & 0.82 & 191.7 \\
\hline 1983 & \multicolumn{2}{|c|}{$\begin{array}{c}2.941 \\
(0.091)\end{array}$} & \multicolumn{2}{|c|}{$\begin{array}{c}0.0045 \\
(0.0004)\end{array}$} & 36 & 0.81 & 148.4 \\
\hline \multicolumn{8}{|c|}{$\begin{array}{l}\text { Multisource regression analysis: } 1982 \text { versus } 1983 \\
\text { year-class }\end{array}$} \\
\hline \multirow[t]{2}{*}{ Model } & \multicolumn{3}{|c|}{ Model } & \multicolumn{2}{|c|}{ Error } & \multirow[t]{2}{*}{ F-value } & \multirow[t]{2}{*}{ p-value } \\
\hline & & DF & SS & DF & MS & & \\
\hline \multicolumn{8}{|c|}{ Test for different slopes } \\
\hline Separate & ines & 3 & 13.66 & 75 & 0.04 & & \\
\hline Parallel li & & 2 & 13.61 & 76 & 0.04 & & \\
\hline Test $b 1=1$ & & 1 & 0.05 & & & 1.38 & 0.2426 \\
\hline \multicolumn{8}{|c|}{ Test for difference in level or intercept } \\
\hline Single lin & & 1 & 12.95 & 77 & 0.04 & & \\
\hline Parallel & & 2 & 0.6623 & & & 16.47 & $<0.001$ \\
\hline
\end{tabular}

estimates over the entire period of residence in both habitat types were obtained for the 1982 year-class. For the 1983 year-class, abundance estimates in the marsh creek did not cover the entire period of residence; however, sampling period covered the entire period of 
open bay residency. Because sampling in the marsh creek habitat ended March 1983, this estimate of mortality was based on a shorter time span, fewer samples and a smaller size range than other estimates.

Estimates of mortality did not differ between habitats within a single year-class, but the overall mortality rate for the 1983 year-class was higher than the mortality rate for the 1982 year-class. Cumulative total abundance of gulf menhaden was related to length for both marsh creek and open bay habitats (Table 2). For both year-classes, analysis indicated no difference in slope ( $\mathrm{m}$ ) between marsh and open bay habitats (Table 2). This analysis also indicated a difference in level or intercept between habitats for the 1982 year-class, but not the 1983 year-class. The difference between habitats was a result of the difference in fish abundance in 2 habitats, and is related to the number of samples taken in each habitat. The lack of difference in level for the 1983 year-class is thought to be a result of fewer samples. For this reason, I have chosen to retain separate estimates of $\mathrm{m}$ for each habitat. The estimates of instantaneous mortality per day $(Z)$ ranged between 0.0075 and 0.0208 and averaged 0.007 and 0.018 for the 1982 and 1983 year-classes, respectively (Table 3).

\section{DISCUSSION}

\section{Migratory pattern}

The migration pattern of gulf menhaden, which involves the sequential use of marsh creek and open bay areas, results in rapid growth and high survival. The rapid exploitation of a temporarily abundant food supply has been hypothesized as a major determinant in the evolution of migratory patterns (Nikolsky 1963 , Northcoate 1978). Prominent among the hypotheses proposed to explain the widespread use of estuaries as nursery habitat is the concept that these areas provide a refuge from predation in a location where food supplies are abundant and physical factors are suitable (Joseph 1973, Deegan \& Day 1984, Deegan \& Thompson 1985). Gulf menhaden's migration pattern coincides with the sequentially available, but spatially separate, food availability peaks in marsh and open bay in estuarine areas (Fig. 8). By occupying tidal creeks early in the year, they can use food available from the flushing of detritus off the marsh surface. In the marsh creeks, gulf menhaden transform from zooplanktivores to filter feeding omnivores that consume phytoplankton, zooplankton, and detritus (Darnell 1961, Deegan et al. 1990). In mid-summer, when food availability in the tidal creeks begins to decline, the fish move to the open bay area where phytoplankton and zooplankton are increasing. Secondly, by using marsh
Table 2. Brevoortia patronus. Regression coefficients (and standard errors) with corresponding statistics for the relationship between total number and length for the 1982 and 1983 year-classes at marsh and open bay habitats. Model fitted was $\ln$ (total number) $=\mathrm{a}+\mathrm{m} \cdot \ln ($ length)

\begin{tabular}{|c|c|c|c|c|c|}
\hline $\begin{array}{l}\text { Regression co } \\
\text { Year-class } \\
\text { and habitat }\end{array}$ & $\begin{array}{l}\text { efficients f } \\
\text { Intercept } \\
\text { (a) }\end{array}$ & $\begin{array}{l}\text { r total nu } \\
\text { Slope } \\
\text { (m) }\end{array}$ & $\begin{array}{c}\text { nber } \\
\mathrm{n}\end{array}$ & $\begin{array}{c}\text { versu: } \\
r^{2}\end{array}$ & $\begin{array}{l}\text { length } \\
\text { F-value }\end{array}$ \\
\hline \multicolumn{6}{|c|}{1982 year-class } \\
\hline Marsh creek & $\begin{array}{c}15.8591 \\
(1.4610)\end{array}$ & $\begin{array}{l}-2.4585 \\
(0.4122)\end{array}$ & 16 & 0.72 & 35.5 \\
\hline Open bay & $\begin{array}{c}13.8591 \\
(2.7132)\end{array}$ & $\begin{array}{l}-2.6519 \\
(0.6413)\end{array}$ & 20 & 0.49 & 17.1 \\
\hline \multicolumn{6}{|c|}{1983 year-class } \\
\hline Marsh creek & $\begin{array}{c}22.0426 \\
(5.1165)\end{array}$ & $\begin{array}{l}-4.6766 \\
(1.5039)\end{array}$ & 11 & 0.59 & 9.6 \\
\hline Open bay & $\begin{array}{c}25.9190 \\
(4.4016)\end{array}$ & $\begin{array}{l}-5.5930 \\
(1.0440)\end{array}$ & 18 & 0.64 & 28.7 \\
\hline
\end{tabular}

Multisource regression analysis: 1982 year-class: marsh creek versus open bay

$\begin{array}{cccc}\text { Model Model } & \text { Error } & \text { F-value p-value } \\ & \text { DF } & \text { SS DF } & \end{array}$

Test for different slopes

$\begin{array}{lllll}\text { Separate lines } & 3 & 193.06 & 32 & 0.2213\end{array}$

Parallel lines $2 \begin{array}{llll}2 & 193.05 & 33 & 0.2151\end{array}$

$\begin{array}{llll}\text { Test } \mathrm{b} 1=\mathrm{b} 2 & 1 & 0.0145 & 0.65\end{array}$

0.799

Test for difference in level or intercept

$\begin{array}{lllll}\text { Single line } & 1 & 173.05 & 34 & 0.7968 \\ \text { Parallel } & 1 & 193.05 & 33 & 0.2151\end{array}$

Test

$\mathrm{a} 1=\mathrm{a} 2 / \mathrm{b} 1=\mathrm{b} 2 \quad 1 \quad 19.99 \quad 92.97<0.001$

Multisource regression analysis: 1983 year-class: marsh creek versus open bay

Model Model Error F-value p-value DF SS DF MS

Test for different slopes

$\begin{array}{lllll}\text { Separate lines } & 3 & 126.26 & 25 & 0.7684\end{array}$

Parallel lines $\quad 2 \quad 126.05 \quad 26 \quad 0.7471$

Test b1 =b2 1

$0.2781 \quad 0.6026$

Test for difference in level or intercept

$\begin{array}{lllll}\text { Single line } & 1 & 125.86 & 27 & 0.7264\end{array}$

$\begin{array}{lllll}\text { Parallel } & 2 & 126.05 & 26 & 0.7471\end{array}$

Test

$\mathrm{a} 1=\mathrm{a} 2 / \mathrm{b} 1=\mathrm{b} 2$

$0.2530 \quad 0.6192$

creeks early in the year, when temperatures there are warmer than open bay temperatures, fish grow more rapidly than if they remained in colder open bay waters. The combination of warm water and high productivity in tidal creeks in the spring is an environment that promotes rapid growth.

The timing of gulf menhaden migration from marsh creeks to open bay areas differs among estuarine sys- 
Table 3. Brevoortia patronus. Estimate (and standard error) of instantaneous mortality (Z) per day for the 1982 and 1983 year-classes in marsh and open bay habitats. Estimates of $\mathrm{Z}$ and standard error are based on equations in text

\begin{tabular}{|lcc|}
\hline Year-class & Marsh creek & Open bay \\
\hline 1982 & 0.0075 & 0.0085 \\
& $(0.0023)$ & $(0.0034)$ \\
1983 & 0.0167 & 0.0209 \\
& $(0.0071)$ & $(0.0050)$ \\
Analysis of differences in mortality rates & \\
Model & t-value & Significance \\
\hline 1982 year-class & 0.41 & Not different \\
1983 year-class & 1.19 & Not different \\
1982 versus 1983 year-class & 2.24 & Different \\
\hline
\end{tabular}

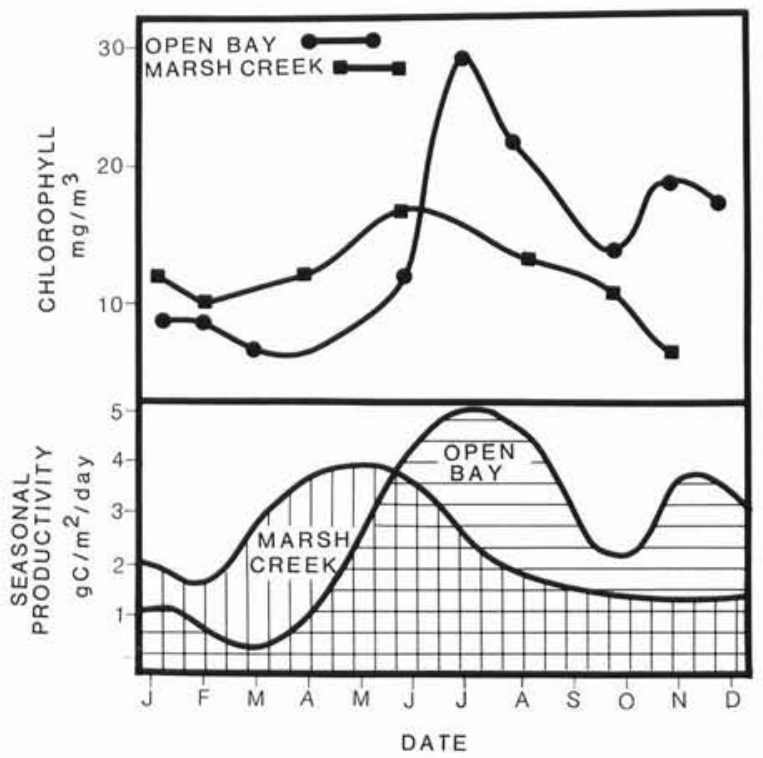

Fig. 8. Estimated productivity cycle in marsh and open bay habitats in Fourleague Bay, Louisiana. Productivity and chlorophyll values are based on measurements taken at open bay and marsh stations (from Deegan 1986, Madden et al. 1988)

tems in Louisiana and may relate to differences in timing of primary productivity. Detrital productivity occurs for a longer time period and peak phytoplankton productivity is later in Fourleague Bay compared to Barataria Bay or Lake Pontchartrain because of the influence of the Atchafalaya River (Deegan \& Thompson 1985, Madden et al. 1988). Thus, if menhaden are migrating in response to food availability, the fish in Lake Pontchartrain should migrate out of tidal creeks earlier than fish in Fourleague Bay. Hinchee (1977) found that gulf menhaden in Lake Pontchartrain begin migrating from tide creeks to open bay areas in May/ June, earlier than fish in Fourleague Bay. The availa- bility of food is considered the most important life requisite for determining the habitat suitability for gulf menhaden (Christmas et al. 1982). Further research documenting the timing of migration relative to the production available in tidal creeks and open bay areas is needed.

Migration from tidal creeks to open bay areas is usually size related, with the larger fish migrating first (Figs. $5 \& 6$ ). Evidence for this is the larger size of individuals in the open bay compared to the marsh creek in June and a plateau in the mean length of the population, along with an increase in size range, in open bay areas during June and July (Figs. 5 \& 6). At the same time the mean length of the population in the marsh creek remains at around $50 \mathrm{~mm}$. This indicated that while some individuals in open bay areas were getting larger, their effect on mean population length was offset by the influx of smaller sized individuals from the marsh creeks. After the major period of migration from marsh creeks to the open bay was over, mean population size in open bay areas increased rapidly. Hinchee (1977) compared the size frequency of gulf menhaden captured in a tidal creek to fish found in open bay samples and also concluded that they migrate out of tidal creeks in a size-related manner at about 45 to $50 \mathrm{~mm}$. Loesch's (1976) study in Mobile Bay, Alabama (USA), also found that smaller menhaden were caught in nearshore environments in January to April, while larger fish were caught in open bay areas, primarily from May to November.

Although size-related migration in estuarine fish is common (Hoese et al. 1968, Herke 1977, Yakupzack et al. 1977, Weinstein \& Walters 1981), few hypotheses to explain it have been offered. I suggest that the seasonal changes in productivity and temperature, combined with the increased metabolic demands of larger fish, account for the size-related migration of estuarine fish. By moving into tidal creeks early in the year during the period of high food availability and warm temperatures fish grow quickly. Later in the summer, however, temperatures in tidal creeks are very high, often near tolerance levels, and food availability declines. The energy required to support metabolism at these high temperatures is greater than at low temperatures (Wohlschlag \& Cech 1970, Brett 1979) and in addition, larger fish require more energy per unit length (Hoar et al. 1979). The higher energy required, combined with lower food availability in tidal creeks in mid to late summer, means larger fish may not be able to meet their energy needs. Depression of growth due to high summer temperatures has been demonstrated for striped mullet (Cech \& Wohlschlag 1975) and possibly spot (Weinstein \& Walters 1981). Deegan (1986) also found that the average energy content of gulf menhaden that remained in tidal creeks after the peak emi- 
gration decreased, and was less than those which migrated to open bay areas. When daily energy intake is less than maintenance level the energy content decreases (Elliott 1979), indicating the fish in the tidal creeks may not have met their daily energy requirements, while those in the open bay did. In addition, large fish in a species are generally less tolerant of high temperatures than small fish (Wohlschlag \& Cech 1970 , Brett 1979). Thus, larger fish respond first, and migrate to deeper, open bay areas, where temperatures are lower and food supply is greater.

Other factors believed to influence gulf menhaden habitat selection are salinity and turbidity (Christmas et al. 1982, Lassuy 1983). Juvenile gulf menhaden are most abundant in salinities from 5 to $10 \%$ but have been found in salinity as high as $60 \%$ (Gunter 1961). All of Fourleague Bay was well within the preferred salinity of menhaden in this study. In other estuaries, salinity may have a more important effect on the distribution of gulf menhaden. Christmas et al. (1982) included substrate type and turbidity (as defined by water color) as parameters in their model of habitat suitability. Both of these parameters related to the availability of food. They assumed that currents and wave action would resuspend organic detritus in muddy environments and that turbidity was a measure of nutrients and organic detritus in areas influenced by incoming freshwater. In Fourleague Bay, the entire estuary is mud-bottomed and turbidity (as measured by Secchi disk depth) was influenced by both wind resuspension of detritus and river flow. Thus, neither of these factors differed between habitats or years. The association of juveniles with high-temperature, lowsalinity, mud-bottomed areas may simply reflect selection for areas of high productivity.

\section{Growth and mortality}

Growth and mortality of juvenile gulf menhaden were correlated with environmental conditions in the estuary (Table 4). High river discharge and low February water temperature were correlated with decreased growth and survivorship; warmer temperatures in late winter, along with lower river discharge, were correlated in larger fish at the end of the year.

Important periods of growth were late spring and early summer (May to July) in marsh creeks and late summer through fall (July to November) in open bay areas (Fig. 4). Early in the year, the average size of larvae captured in open bay stations remained fairly constant indicating that larvae were either not growing at the cold temperatures of open bay stations, or that a prolonged period of recruitment occurred. In marsh creeks, with the onset of warm weather and the com- pletion of the transformation, menhaden grew rapidly. Springer \& Woodburn (1960), in a comparison of gulf menhaden growth from Florida and Louisiana, also found an apparent burst of growth after May.

The growth rates estimated in this study ( $G$ values of 0.004 to 0.005 ) compare reasonably well with other estimates of growth for gulf menhaden. Loesch (1976), based on length-frequency analysis, estimated a G of 0.0045 for juvenile gulf menhaden in Mobile Bay, Alabama. The $G$ of 0.0051 obtained by length frequency analysis for the 1982 year-class is close to the 0.0055 obtained by otolith analysis for this same population (Deegan \& Thompson 1987). The G based on otoliths is not strictly comparable to the G in this study because the size ranges of fish used were different. The otolith analysis was restricted to fish less than $50 \mathrm{~mm}$; this analysis included fish up to $105 \mathrm{~mm}$. Because smaller fish tend to have a higher $G$ than larger fish, the $\mathrm{G}$ estimated from the otolith study should be slightly higher than the $\mathrm{G}$ estimated from the length-frequency (Brett 1979).

Although there were differences between yearclasses, mortality of juvenile gulf menhaden was relatively low. My estimates of mortality ranged from 0.007 to 0.0208 , and are consistent with the expected trend; mortality in juvenile gulf menhaden is lower than larval mortality for an ecologically similar species, and higher than the estimate for adult gulf menhaden. Dahlberg (1979) reported daily mortality rates of between 0.162 and 0.030 for larvae and post larvae of other marine and freshwater fishes, and a daily mortality rate of 0.030 for Atlantic herring, another pelagic, marine, schooling clupeid. The annual mortality of 1 -yr-old gulf menhaden has been estimated at 1.09, which is approximately a daily mortality of 0.0029 (Ahrenholtz 1981, Nelson \& Ahrenholtz 1986). Low mortality is often suggested as a reason for the use of estuarine habitats as nursery areas (Joseph 1973, Deegan \& Day 1984). The estimates of mortality for juvenile gulf menhaden were lower than the $0.03 \mathrm{~d}^{-1}$ average reported by Gulland (1964) for juvenile marine fish, suggesting that the use of estuaries as nurseries may decrease mortality

Table 4. Summary of relationship between estuarine environmental conditions and gulf menhaden population dynamics

\begin{tabular}{|lllc|}
\hline Characteristic & \multicolumn{3}{c|}{ Year-class } \\
& 1981 & 1982 & 1983 \\
\hline River discharge & Low & Normal & High \\
Winter water temperature & High & Normal & Low \\
End of year fish length $(\mathrm{mm})$ & $90-135$ & $80-110$ & $70-100$ \\
End of year fish weight $(\mathrm{g})$ & $18-20$ & $13-15$ & $8-11$ \\
Mortality rate $\left(\mathrm{d}^{-1}\right)$ & & 0.007 & 0.018 \\
Growth rate $\left(\mathrm{d}^{-1}\right)$ & & 0.005 & 0.004 \\
& & & \\
\hline
\end{tabular}


in the juvenile stage. The high survival of young-ofthe-year could be an evolutionary driving force behind the development of the complex estuarine-dependent migration pattern.

It is important to remember that this method only allows statistical characterization of the mortality rate of a particular time period. It does not predict mortality for individuals nor does it allow prediction of mortality under different circumstances. It is also important to note that the confidence limits on the mortality estimate were derived from the variance associated with $G$ and $\mathrm{M}$. These variances included not only sampling variation, but also include natural variation due to individual responses to the environment.

Young-of-the-year gulf menhaden growth apparently slows during periods of high river discharge and cold winter temperatures and mortality is increased (Table 4). Although the instantaneous relative growth rates were not statistically different between yearclasses, the mean value of $\mathrm{G}$ for the 1982 year-class was higher than the 1983 year-class and the 1982 year-class also attained a larger size at the end of the year than the 1983 year-class, suggesting these fish grew faster. The largest fish were taken in 1981 which had the lowest river discharge and the warmest winter months. Mortality of the 1982 year-class was lower than the 1983 yearclass, suggesting the faster-growing fish have a lower mortality rate (Table 4). High river discharge and cold temperatures may decrease survival in a manner similar to growth. The higher river discharge, and severe freezing weather in January 1983, resulted in colder water temperatures in February and March than the previous year. The high river discharge continued throughout 1983 and prolonged low salinities (sometimes almost zero) well into the late summer and early fall.

The combination of low water temperatures and high river discharge probably caused decreased algal productivity. Mid-summer chlorophyll levels were higher in 1982 than 1983, and resulted in slower growth, and smaller fish at the end of the year. The pattern of high growth/low mortality is also consistent with densitydependent phenomena. Density-dependent relationships cannot be ruled out; however, there was no difference in the average abundance in Fourleague Bay between the 1982 and 1983 year-classes.

Other studies (Stone 1976, Guillory et al. 1983), based on correlation of commercial catch of age-1 gulf menhaden with environmental variables, have suggested that early residency in the estuarine nursery area is a critical determinant of recruitment. Significant negative correlations were found between catch of age-1 fish and winter water temperature, and river discharge for the year of their estuarine residency (Guillory et al. 1983). Christmas et al. (1982) also suggested that habitat suitability was negatively corre- lated with low winter temperatures. My work confirms that these statistical correlations have a basis in the growth and mortality processes during the estuarine residence period.

Gulf menhaden exhibit a life-history pattern that is typical of many species which use estuaries as a nursery ground. The sequential use of habitats related to productivity, and population dynamics influenced by environmental characteristics which govern food availability and metabolic demands, are probably typi$\mathrm{cal}$ of other fishes with this life history pattern. Applying these concepts to evaluating the population dynamics of other estuarine-dependent species may aid in understanding the basis of statistical relationships between adult fisheries yields and environmental conditions during the young-of-the-year stay in estuarine areas.

Acknowledgements. This work was funded by grants from Sea Grant, Sigma Xi, the Department of Marine Sciences and the Coastal Fisheries Program at Louisiana State University. I thank Drs B. Thompson, V. Wright and W. Kelso for comments on earlier drafts and C. Neill and C. Moncrieff for field help. Two anonymous reviews substantially improved the final manuscript.

\section{LITERATURE CITED}

Ahrenholtz, D. W. (1981). Recruitment and exploitation of gulf menhaden, Brevoortia patronus. Fish. Bull. U.S. 79: 325-335

Brett, J. R. (1979). Environmental factors and growth. In: Hoar, W. S., Randall, D. J., Brett, J. R. (eds.) Fish physiology Vol. VIII. Bioenergetics and growth. Academic Press, New York, p. 599-677.

Cech, J. J. Jr, Wohlschlag, D. E. (1975). Summer growth depression in the striped mullet, Mugil cephalus L. Contr. mar. Sci. 19: 92-100.

Christmas, J. Y., McBee, J. T., Waller, R. S., Sutter, F. C. III. (1982). Habitat suitability index models: gulf menhaden. US Department of the Interior Fisheries and Wildlife Service FWS/OBS-82/10.23

Clark, S. H. (1974). A study of variation in trawl data collected in Everglades National Park, Florida. Trans. Am. Fish. Soc. 103: 777-785

Dahlberg, M. D. (1979). A review of survival rates of fish eggs and larvae in relation to impact assessments. Mar. Fish. Rev. 41 (3): 1-12

Darnell, R. M. (1961). Trophic spectrum of an estuarine community based on studies of Lake Pontchartrain, Louisiana. Ecology 42 (3): 553-568

DeAngelis, D. L., Hackney, P. A., Webb, J. C. (1980). A partial differential equation model of changing sizes and numbers in a cohort of juvenile fish. Environ. Biol. Fish. 5 (3): 261-266

Deegan, L. A. (1985). The population ecology and nutrient transport of Gulf menhaden in Fourleague Bay, Louisiana. $\mathrm{Ph}$. D, thesis, Louisiana State University, Baton Rouge

Deegan, L. A. (1986). Changes in body composition and morphology of young-of-the-year gulf menhaden, Brevoortia patronus Goode, in Fourleague Bay, Louisiana. J. Fish Biol. 29: 403-415 
Deegan, L. A., Day, J. W. Jr (1984). Estuarine fishery habitat requirements. In: Copeland, B. J., Hart, K., Davis, N., Friday, S. (eds.) Research for managing the nation's estuaries: proceedings of a conference in Raleigh, North Carolina. UNC Sea Grant College Publication UNC-SG84-08, Raleigh, p. 315-336

Deegan, L. A., Thompson, B. A. (1985). The ecology of fish communities in the Mississippi River deltaic plain. In: Yanez-Arancibia, A. (ed.) Fish community ecology in estuaries and coastal lagoons: towards an ecosystems integration. UNAM-ICML Publishers, Mexico City, p. $35-56$

Deegan, L. A., Thompson, B. A. (1987). Growth rate and life history events of young-of-the-year gulf menhaden as determined by otoliths. Trans. Am. Fish. Soc. 116: 663-667

Deegan, L. A., Peterson, B. J., Portier, R. (1990). Stable isotopes and cellulase activity as evidence for detritus as a food source for juvenile gulf menhaden. Estuaries 13 (1): $14-19$

Draper, N., Smith, H. (1981). Applied regression analysis, 2nd edn. John Wiley and Sons, New York

Elliott, J. M. (1979). Energetics of freshwater teleosts. In: Miller, P. J. (ed.) Fish phenology: anabolic adaptiveness in teleosts. Symposia of the Zoological Society of London No. 44. Academic Press, New York, p 29-62

Guillory, V., Bejarano, R. (1980). Evaluation of juvenile menhaden abundance data for prediction of commercial harvest. Proceedings Annual Conference Southeastern Fish and Wildlife Agencies 34: 193-203

Guillory, V., Geaghan, J., Roussell, J. (1983). Influence of environmental factors on gulf menhaden recruitment. Louisiana Department of Wildlife and Fisheries. Tech. Bull. No. 37

Gulland, J. A. (1964). Survival of the youngest stages of fish and its relation to year class strength. ICNAF Spec. Publ. 6: 363-372

Gunter, G. (1961). Some relations of estuarine organisms to salinity. Limnol. Oceanogr. 6: 182-190

Herke, W. (1977). Life history concepts of motile estuarinedependent species should be re-evaluated. Library of Congress Catalog No. 77-90015. Available from Dr. Herke, School of Forestry, Wildlife and Fisheries, Louisiana State University, Baton Rouge, Louisiana

Hinchee, R. (1977). Selected aspects of the biology of Lake Pontchartrain, Louisiana. Master's thesis, Louisiana State University, Baton Rouge

Hoar, W. S., Randall, D. J., Brett, J. R. (eds.). (1979). Fish physiology Vol. VIII. Bioenergetics and growth. Academic Press, New York

Hoese, H. D., Copeland, B. J., Mosely, F. N., Lane, E. D. (1968). Fauna of the Aransas Pass Inlet, Texas. III. Diel and seasonal variations in trawlable organisms of the adjacent area. Texas J. Sci. 20: 33-60

Joseph, E. B. (1973). Analysis of a nursery ground. In: Pacheco, A. L. (ed.) Proceedings of a workshop on egg, larval, and juvenile stages of fish in Atlantic Coast Estuaries. Tech. Publ. No. 1. NOAA, NMFS, Mid-Atlantic Coast Fisheries Center, Highlands, NJ, p. 118-121

Lassuy, D. R. (1983). Species profiles: life histories and environmental requirements (Gulf of Mexico) - Gulf menhaden. US Fish and Wildlife and US Army Corps of Engineers, TR EL-82-4, Slidell, Louisiana

This article was presented by Professor R. L. Haedrich, St. John's, Nfld, Canada
Loesch, H. C. (1976). Observations of menhaden recruitment and growth in Mobile Bay, Alabama. Proceedings of the Alabama Academy of Science 39: 35-42

Madden, C. J., Day, J. W. Jr, Randell, J. M. (1988). Freshwater and marine coupling in estuaries of the Mississippi River deltaic plain. Limnol. Oceanogr. 33 (4): 982-1004

Nelson, W. R., Ahrenholtz, D. W. (1986). Population and fishery characteristics of Gulf menhaden, Brevoortia patronus. Fish. Bull. U.S. 84: 311-325

Nikolsky, G. V. (1963). The ecology of fishes. Academic Press, New York

Northcoate, T. G. (1978). Migratory strategies and production in freshwater fishes. In: Gerking, S. D. (ed.) Ecology of freshwater fish production. John Wiley and Sons, New York, p. 326-359

Reintjes, J. W., Pacheco, A. T. (1966). The relationship of menhaden to estuaries. Spec. Publs Am. Fish. Soc. 3: $50-58$

Ricker, W. E. (1975). Computation and interpretation of biological statistics of fish populations. Bulletin 191. Canada Fisheries and Marine Service, Ottawa, Canada

Ricker, W. E. (1979). Growth rates and models. In: Hoar, W. S., Randall, D. J., Brett, J. R. (eds.) Fish physiology Vol. VIII. Bioenergetics and growth. Academic Press, New York, p. 678-743

Simoneaux, L. F. (1979). The distribution of menhaden, genus Brevoortia, with respect to salinity, in the upper drainage of Barataria Bay, Louisiana. Master's thesis, Louisiana State University, Baton Rouge

Smith, J. W., Levi, E. J., Vaughan, D. S., Hall, E. A. (1987), Gulf menhaden, Brevoortia patronus, purse seine fishery, 1974-1985, with a brief discussion of age and size composition of the landings. NOAA Technical Report NMFS 60

Snedecor, G. W., Cochran, W. G. (1967). Statistical methods. 6 th edn. The Iowa State University Press, Ames

Springer, V. G., Woodburn, K. D. (1960). An ecological study of the fishes of the Tampa Bay area. Florida Board of Conservation Marine Laboratory Professional Paper Series 1

Stone, J. H. (1976). Environmental factors relating to Louisiana menhaden harvest. Louisiana State University Sea Grant Publication No. LSU-T76-004

Tyler, A. V., Gallucci, V. F. (1980). In: Lackey, R. T., Nielson, L. (eds.) Fisheries management. John Wiley and Sons, New York, p. 111-148

Warren, W. G. (1974). The comparison of regressions: a formulation suited to conversational mode operation. J. Statistical Computation Simulation 3: 71-79

Weinstein, M. P., Walters, M. F. (1981). Growth, survival, and production in young-of-the-year populations of Leiostomus xanthrus Lacepede rising in tidal creeks. Estuaries 4: 185-197

White, G. C., Anderson, D. R., Burkham, K. P., Otis, D. L. (1982). Capture-recapture and removal methods for sampling closed populations. Los Alamos National Laboratory, Los Alamos, New Mexico. LA-8787-NERP

Wohlschlag, D. E., Cech, J. J. Jr (1970). Size of pinfish in relation to thermal stress response. Contr. mar. Sci. 15: 21-31

Yakupzack, P. A., Herke, W. H., Perry, W. G. (1977). Emigration of juvenile Atlantic croaker, Micropogon undulatus, from a semi-impounded marsh in southwestern Louisiana. Trans. Am. Fish. Soc. 106 (6): 538-544

Manuscript first received: February 6, 1990

Revised version accepted: August 24, 1990 